\title{
Evolution of groundwater chemistry in coastal aquifers of the Northern Dvina basin (NW Russia)
}

\author{
Alexander Malov ${ }^{1, *}$ \\ ${ }^{1}$ Federal Center for Integrated Arctic Research RAS, 23 Severnoy Dviny Emb., Arkhangelsk, 163061, \\ Russia
}

\begin{abstract}
The specific objective of the study is to clarify the sources and characteristics of groundwater chemistry in coastal aquifers of the Northern Dvina basin. It has been established that the chemical composition of fresh water evolves in the direction $\left(\mathrm{Ca}-\mathrm{Mg}-\mathrm{HCO}_{3}\right)-\left(\mathrm{Na}-\mathrm{HCO}_{3}\right)-(\mathrm{Na}-\mathrm{Cl})$. It is due to successive replacement of the process of calcite dissolution in the recharge area on the watershed i) by the process of hydrolysis of sodium aluminosilicates in the transit zone and ii) by the processes of mixing fresh water with salt water and brines, cation exchange of alkaline earth elements with alkaline elements and dissolution of gypsum near discharge areas at the seashore and in paleovalleys. In the brackish and salty waters the $\mathrm{Na} / \mathrm{Ca}$ ratio is reduced to $1-4$. This indicates that in the aquifers there are other sources of $\mathrm{Ca}$, in addition to the dissolution of gypsum. The most probable process is the hydrolysis of Ca-aluminosilicates, which indicates a significant time of water-rock interaction. The "brackish1" water with TDS 5-6 g. $\mathrm{L}^{-1}$, is particularly distinguished by the degree of modification due to water-rock interaction.
\end{abstract}

\section{Introduction}

The Northern Dvina basin (NDB) area is one of the most developed areas in the European North of Russia. Here, there are significant resources of drinking and mineral groundwater which however are used in extremely limited quantities. This is due to highly complex nature of the hydro-chemical conditions in the aquifers. The territory is located on the seacoast and has been repeatedly flooded by the sea, as evidenced by the almost widespread development of marine deposits of the late Pleistocene and to a lesser extent, mainly near mouths of the rivers flowing into the White Sea, the Holocene. During these periods, salinization of aquifers occurred. In the continental periods, partial desalinization occurred due to atmospheric precipitation infiltrating into the recharge areas and melted glacier waters. periods, salinization of aquifers occurred. In the continental periods, partial desalinization occurred due to atmospheric precipitation infiltrating into the recharge areas and melted glacier waters. Therefore, the chemical composition of groundwater can now be

\footnotetext{
*Corresponding author: malovai@yandex.ru
} 
explained as the mixing of saline seawater with fresh meteoric water, enriched with dissolved matter of the aquifer sediments. The lack of clearly expressed aquicludes between aquifers often leads to temporal variability in the salinity and other water quality parameters, which makes their utilization difficult for various purposes. Therefore, the specific objectives of the study were to clarify the natural evolution of groundwater chemistry in the Late Pleistocene-Holocene. The results of this study provide a better understanding of the interrelationship of various groundwater flows near the coasts and contribute to a more justified and efficient use of them in the recent period of anthropogenic influence. In particular, in this regard the following issues will be clarified: i) the possibility of providing high-quality drinking water from groundwater resources to large cities such as Arkhangelsk, Novodvinsk and Severodvinsk, whose demand for water is more than $300,000 \mathrm{~m}^{3}$ per day. At present, their water supply is provided by surface water which is of low quality; ii) the danger of dumping saline drainage water from an exploited diamond deposit into the rivers. These points determine the ecological significance of the work.

\section{Study object and methods}

Sampling locations are on the NDB, including its slopes. NDB represents an onshore continuation of the Dvina Bay (White Sea). The present-day basin is a sea-facing depression composed of sequences with different ages, namely, the Middle-Upper Carboniferous carbonate-terrigenous, Upper Devonian-Lower Carboniferous terrigenous, and Vendian Padun, Mezen, and Ust-Pinega Formations. The basin at the top is largely filled with clayey sediments from the Mikulinian interglacial Boreal sea. The clays are underlain by a 10 to $15 \mathrm{~m}$ thick sequence of loams from the Moskovian moraine. The underlying Vendian terrigenous sequence $(600-700 \mathrm{~m})$ is composed of alternating sandstones, siltstones, and mudstones.

Fresh water is contained in the Quaternary, Carboniferous, and Vendian aquifers only on the slopes of the NDB. The upper part of the Vendian aquifers in the central part of the basin is characterized by inverse zonality and decreasing groundwater total dissolved solids (TDS) from 28 to $5 \mathrm{~g} \cdot \mathrm{L}^{-1}$. The lower part of the Vendian aquifers is characterized by increasing groundwater TDS from $5 \mathrm{~g} \cdot \mathrm{L}^{-1}$ at a depth of $150-200$ meters to $50-170 \mathrm{~g} \cdot \mathrm{L}^{-1}$ at a depth of 250-800 meters.

Forty-two groundwater samples were collected from Quaternary, Carboniferous, and Vendian aquifers in period 2012-2014, and ten samples were collected in 2006. All of the water samples were filtered through $0.45 \mu \mathrm{m}$ acetate cellulose in the field. The chemical composition were determined as described by Malov [1].

\section{Results}

The TDS of the fresh groundwater in the study area was between 171 and $939 \mathrm{mg} \cdot \mathrm{L}^{-1}$. The TDS had a Ca-Mg- $\mathrm{HCO}_{3}$ composition in the Quaternary and Carboniferous aquifers. In the Vendian aquifer, this composition is typical for groundwater with TDS $\sim$ up to $300 \mathrm{mg} \cdot \mathrm{L}^{-1}$. At TDS $\sim$ up to $600 \mathrm{mg} \cdot \mathrm{L}^{-1}$ water had a $\mathrm{Na}-\mathrm{HCO}_{3}$ composition, at TDS $\sim$ up to $1 \mathrm{~g} \cdot \mathrm{L}^{-1}$ water had a $\mathrm{Na}-\mathrm{Cl}$ composition. In general, samples had slightly alkaline $\mathrm{pH}$ 7.5-8.7, average 8.1 in $\mathrm{Ca}-\mathrm{Mg}-\mathrm{HCO}_{3}$ water and 7.6-9.2, average 8.7 in $\mathrm{Na}-\mathrm{HCO}_{3}$ water. Groundwater temperature was low, in the range $3.7-5.2^{\circ} \mathrm{C}$.

Brackish water has a TDS of 2.5 to $10.1 \mathrm{~g} \cdot \mathrm{L}^{-1}$ and a predominantly $\mathrm{Na}-\mathrm{Cl}$ composition. The maximum dominance of $\mathrm{Na}^{+}$is characteristic of the least mineralized waters (samples 14h, $\mathrm{Kw}, \mathrm{K} 2$ ). The sample $\mathrm{Mi}$ is located in the $\mathrm{Ca}-\mathrm{Mg}-\mathrm{Cl}$ field of the composition; samples 
I5 and $\mathrm{I} 4$, in which the $\mathrm{Ca}^{2+}$ content is $35-40$ meq.\%, are also close to this type of groundwater. Meq\% content of $\mathrm{SO}_{4}{ }^{2-}$ in brackish water is relatively high: 15-46 meq.\%.

Strongly brackish and salty waters in the Padun formation of Vendian aquifers have a TDS of 12.7 to $27.6 \mathrm{~g} \cdot \mathrm{L}^{-1}$ and $\mathrm{Na}-\mathrm{Cl}$ composition. $\mathrm{Meq} \%$ content of $\mathrm{Ca}^{2+}$ and $\mathrm{SO}_{4}{ }^{2-}$ is not high: $18-28$ meq.\% and 8.4-9.7 meq.\%, respectively.

Strongly brackish and salty waters in the Mezen formation of Vendian aquifers have a TDS of 15.6 to $27.5 \mathrm{~g} \cdot \mathrm{L}^{-1}$ and $\mathrm{Na}-\mathrm{Cl}$ composition. $\mathrm{Meq} \%$ content of $\mathrm{Ca}^{2+}$ and $\mathrm{SO}_{4}{ }^{2-}$ is not high: 14-26 meq.\% and 11-19 meq.\%, respectively.

\section{Discussion}

\subsection{Fresh groundwater}
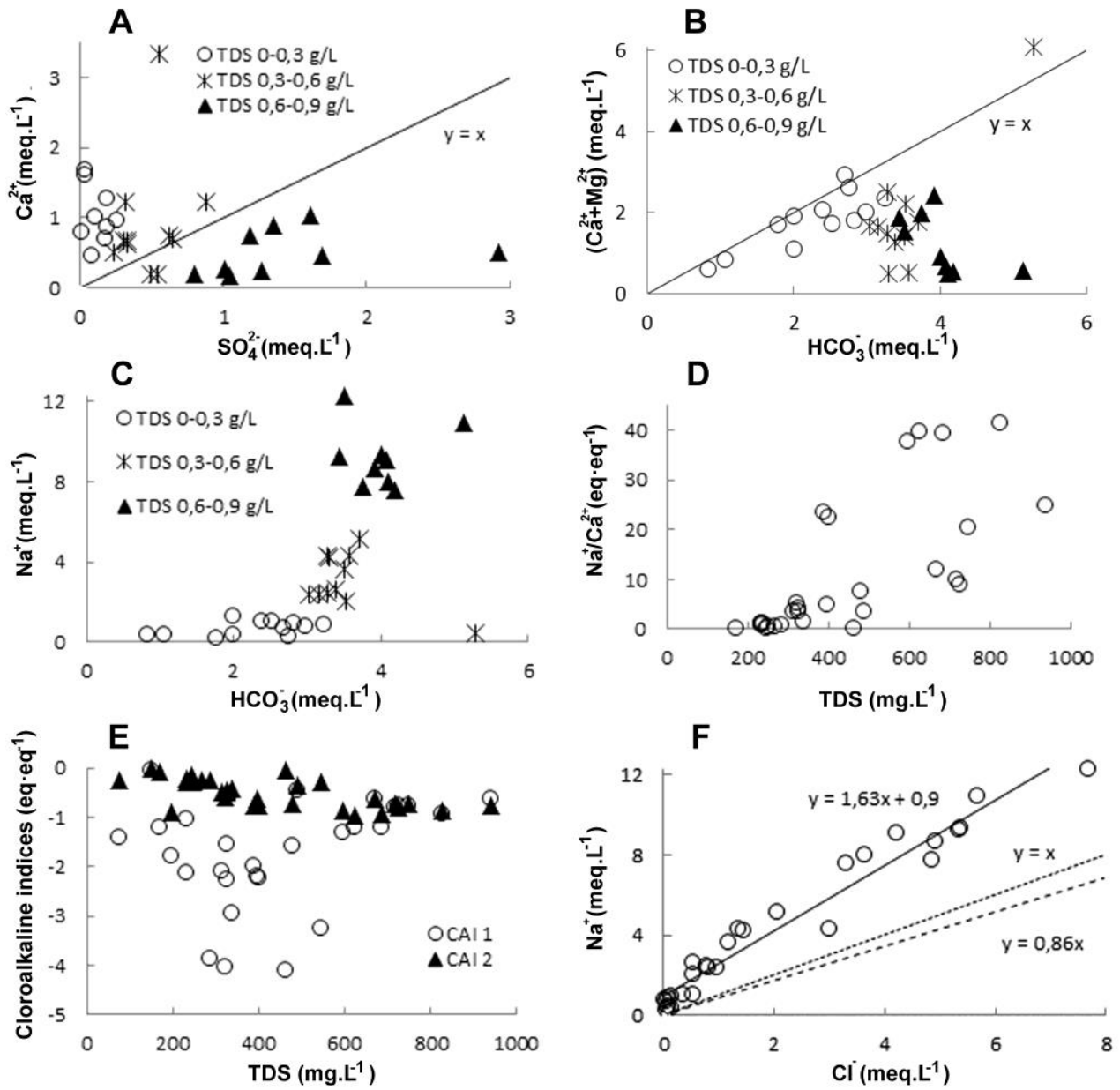

Fig. 1. Diagrams showing element concentrations $\left(\mathrm{meq} \cdot \mathrm{L}^{-1}\right)$ and their ratios $\left(\mathrm{eq} \cdot \mathrm{eq}^{-1}\right)$ in the fresh groundwater and surface water of the study area with TDS groups.

The least mineralized waters (up to $0.3 \mathrm{~g} \cdot \mathrm{L}^{-1}$ ) are undersaturated with respect to gypsum and anhydrite, but since there is no correlation between $\mathrm{SO}_{4}{ }^{2-}$ and $\mathrm{Ca}^{2+}$ and there is a $\mathrm{SO}_{4}{ }^{2-}$ deficiency relative to $\mathrm{Ca}^{2+}$ (Fig. 1a), the dissolution of gypsum plays a subordinate role. For 
these waters, the $\mathrm{Ca}-\mathrm{Mg}-\mathrm{HCO}_{3}$ composition is characteristic. This is due to the disequilibrium of atmospheric precipitation, thawed and least mineralized waters with respect to calcite, anorthite, labradorite, andesine, diopside [2]. On the graph $\left(\mathrm{Ca}^{2+}+\mathrm{Mg}^{2+}\right)$ vs $\mathrm{HCO}_{3}^{-}$(Fig. 1b), a correlation up to $100 \%$ is observed for these waters.

As TDS increases, $\mathrm{Ca}^{2+}$ and $\mathrm{Mg}^{2+}$ deficiency increase. On the graph of $\mathrm{Na}^{+} \mathrm{vs} . \mathrm{HCO}_{3}{ }^{-}$ (Fig. 1c), an opposite picture is observed for these waters; with an increase in TDS, the $\mathrm{Na}^{+}$ milligram equivalent content rises exponentially. Accordingly, the $\mathrm{Na} / \mathrm{Ca}$ ratio increases to 40 (Fig. 1d). The value of chloroalkaline indices [3, 4] is negative (Fig. 1e). For groundwaters with TDS $0.3-0.6 \mathrm{~g} \cdot \mathrm{L}^{-1} \mathrm{Na}-\mathrm{HCO}_{3}$ composition is characteristic. This can be attributed to saturation of groundwater with respect to calcite and dolomite [2] and partial precipitation of calcium carbonates. Simultaneously, the relative role of the hydrolysis of sodium aluminosilicates (Na-montmorillonite, albite) increases [5].

As the TDS level increases further to $0.6-0.9 \mathrm{~g} \cdot \mathrm{L}^{-1}$, the concentration of $\mathrm{Cl}^{-}$increases to $106-272 \mathrm{mg} \cdot \mathrm{L}^{-1}$, due to the processes of mixing fresh water with salt, that are discharged into the river valleys. However, with respect to the theoretical lines of dissolution of halite $(y=x$ in Fig. 1f) and dilution of sea water $(y=0.86 x)$, the sodium content is increased by a factor of 1.5-2. This testifies to the essential role of other processes of $\mathrm{Na}^{+}$transition into the solution. The supersaturation of groundwater with respect to albite increases substantially [2], so that the presence of a cation exchange of alkaline earth elements with alkaline elements can be assumed. Fig. 1a shows a deficiency of $\mathrm{Ca}^{2+}$ with respect to $\mathrm{SO}_{4}{ }^{2-}$, that is, the minimum $\mathrm{Ca}^{2+}$ concentrations (on average, $11 \mathrm{mg} \cdot \mathrm{L}^{-1}$ ) at the fresh groundwater with a mineralization of $0.6-0.9 \mathrm{~g} \cdot \mathrm{L}^{-1}$ are maintained mainly by dissolution of gypsum.

\subsection{Brackish and salty groundwater}
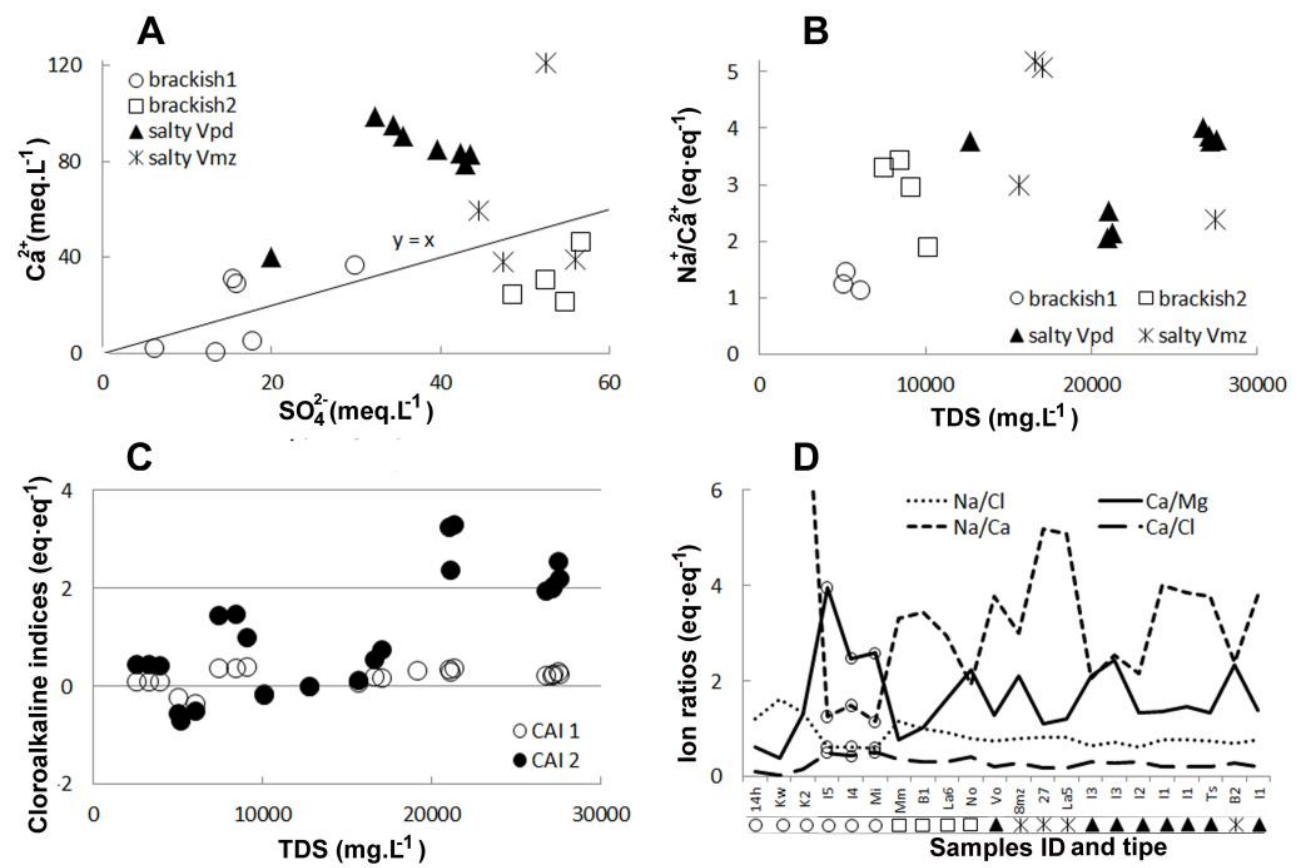

Fig. 2. Diagrams showing element concentrations $\left(\mathrm{meq} \cdot \mathrm{L}^{-1}\right)$ and their ratios $\left(\mathrm{eq} \cdot \mathrm{eq}^{-1}\right)$ in the brackish and salty groundwater of the study area with major chemical groups. 
In the Ca- $\mathrm{SO}_{4}$ diagram (Fig. 2a), the $\mathrm{SO}_{4}{ }^{2-}$ deficiency relative to $\mathrm{Ca}^{2+}$ is noted for all the strongly brackish and salty waters in the Padun formation of Vend aquifers ( "salty Vpd" in Fig. 2a), and also for three samples I5, I4, Mi of the brackish water in the Padun formation of Vendian aquifers ("brackish1" in Fig. 2a) and two samples of the strongly brackish and salty waters in the Mezen formation of Vendian aquifers (B2, 8mz) ("salty Vmz" in Fig. 2a). In these samples, the $\mathrm{Na} / \mathrm{Ca}$ ratio is reduced to 1-4 (Fig. 2b), chloroalkaline indices are positive (Fig. 2c).

This indicates that in the aquifers there are other sources of $\mathrm{Ca}$, in addition to the dissolution of gypsum. The most probable process is the hydrolysis of $\mathrm{Ca}$-aluminosilicates, nonequilibrium with brackish and salt groundwater [6].

This process follows the mechanism of diffusion kinetics [7], which indicates a significant time of water-rock interaction for these samples. The samples I5, I4, Mi, characterizing the "brackishl" water with TDS 5-6 $\mathrm{g} \cdot \mathrm{L}^{-1}$, are particularly distinguished by the degree of modified due to water-rock interaction (Fig. 2d).

\section{Conclusion}

It has been established that the chemical composition of fresh water evolves in the direction $\left(\mathrm{Ca}-\mathrm{Mg}-\mathrm{HCO}_{3}\right)-\left(\mathrm{Na}-\mathrm{HCO}_{3}\right)-(\mathrm{Na}-\mathrm{Cl})$. It is due to successive replacement of the process of calcite dissolution in the recharge area on the watershed i) by the process of hydrolysis of sodium aluminosilicates in the transit zone and ii) by the processes of mixing fresh water with salt water and brines, cation exchange of alkaline earth elements with alkaline elements and dissolution of gypsum near discharge areas at the seashore and in paleovalleys. In the fresh water the $\mathrm{Na} / \mathrm{Ca}$ ratio is increased to 40 .

In the brackish and salty waters the $\mathrm{Na} / \mathrm{Ca}$ ratio is reduced to $1-4$. This indicates that in the aquifers there are other sources of $\mathrm{Ca}$, in addition to the dissolution of gypsum. The most probable process is the hydrolysis of Ca-aluminosilicates, which indicates a significant time of water-rock interaction. The "brackish1" water with TDS 5-6 g. L-1, is particularly distinguished by the degree of modification due to water-rock interaction.

This work was supported by the Russian Foundation for Basic Research (projects no. 18-0560151_Arctic, no. 18-05-01041_A), the Federal Agency of Scientific Organizations (project no. 0409-2019-0017) and the UB RAS (project no. AAAA-A18-118012390242-5). The author wishes to thank O. S. Pokrovsky, A. Savenko for the analytical determinations.

\section{References}

1. A. Malov, J Environ. Radioactiv., 153, 61-67 (2016)

2. A. Malov, E. Sidkina, B. Ryzhenko, Geochem. Int. 55, 1118-1130 (2017)

3. H. Schoeller, In: Methods and techniques of groundwater investigation and development. Water Res. (UNESCO, Paris, 1967)

4. H. Schoeller, In: Groundwater studies - an international guide for research and practice (UNESCO, Paris, 1977)

5. S. Shvartsev, In: Fundamental problems of modern hydrogeochemistry (Sci. Technol. Publ. House, Tomsk, 2004) (in Russian)

6. V. Zverev, Role of groundwater in migration of chemical elements (Nedra, Moscow, 1982) (in Russian)

7. H. Helgeson, Geochim. Cosmochim. Acta 35, 421-469 (1971) 